\title{
ALGEMENE GESCHIEDENIS
}

P. H. H. Vries, Verhaal en betoog. Geschiedbeoefening tussen postmoderne vertelling en sociaal-wetenschappelijke analyse (Dissertatie Leiden 1995, Leidse historische studiën I; Leiden: Centrum voor moderne geschiedenis, 1995, 655 blz., ISBN 907530101 4).

Deze omvangrijke dissertatie (415 bladzijden tekst, 170 bladzijden noten) beschrijft en analyseert vanuit wetenschapsfilosofisch gezichtspunt een opvallende verschuiving die de geschiedbeoefening (nationaal en internationaal) de afgelopen decennia te zien heeft gegeven: de aandacht verschoof van 'structuur' naar 'cultuur', van de 'objectieve structuren' naar de 'belevingswerelden' in vroeger tijden. Deze omslag in het aandachtsveld heeft in de ogen van de auteur afbreuk gedaan aan het wetenschappelijk gehalte van de geschiedbeoefening; sommigen gooiden al te snel het kind (de wetenschap) met het badwater weg. Als wetenschapsfilosoof eist de auteur bovenal 'precisie' en 'strakke definities', termen die telkens weer opduiken in zijn betoog. Wat dat betreft blijkt er nogal wat te schorten in de beide historische kampen, die hij onderscheidt, al maken 'leef-wereldhistorici' het zijns inziens in dit opzicht bonter dan 'structuurhistorici'. Niemand komt vlekkeloos of ongeschonden van zijn 'snijtafel' af. Nog een ander beeld gebruikt de auteur om zijn aanpak te verduidelijken: dat van de scheidsrechter, die constant gele maar vooral rode kaarten uitdeelt. Vries verkiest een correcte (en door de vele spelonderbrekingen soms saaie) wedstrijd boven een aangename en verrassende. Om een nog wat negatiever beeld van de socioloog Goudsblom te gebruiken: men waant zich bij lezing van dit boek bij tijd en wijle in een schiettent.

De bewust gekozen invalshoek van de Leidse historicus Peer Vries heeft duidelijk bepaalde voordelen. De eis tot 'precisie' en 'strakke definities' maakt duidelijk — voorzover we het nog niet wisten - hoe losjes en nonchalant wetenschappers (niet alleen historici) kunnen omspringen met gewichtige en veel gehanteerde begrippen als theorie, generalisatie en structuur. Het is vanzelfsprekend van geen gering belang telkens weer goed te beseffen welke verschillende betekenissen aan deze centrale begrippen worden toegekend. Zulk een besef kan helpen verwarring te voorkomen, het dwingt ook tot bescheidenheid in het formuleren van wetenschappelijke doelstellingen. De kritische auteur is door zijn aanpak dan ook herhaaldelijk in staat allerlei pretenties door te prikken. Er is nog iets dat bij lezing opvalt. Wanneer men de in dit boek toegelichte debatten volgt, ontkomt men niet aan de indruk dat een zekere vorm van narcisme voor de voortgang van de wetenschap onmisbaar is. Men wil nu eenmaal graag tonen dat men met iets nieuws komt, dat de voorganger of tegenstander ontgaan is. Niet zelden evenwel ontsiert en stagneert zulk een narcisme het wetenschappelijk debat, dat gewoon zinloos wordt doordat men het standpunt van de tegenstander of voorganger doodeenvoudig geen recht doet en al of niet bewust eenzijdig of verkeerd interpreteert. Het standpunt van de tegenstander wordt maar al te dikwijls 'gemaltraiteerd'. Men creëert dan karikaturen, men bestrijdt 'waanvoorstellingen', men schiet op kleiduiven. Het is een herhaaldelijk geuite klacht in dit boek $(227,299,359)$. Men leest 'moedwillig' verkeerd of eenzijdig om de nieuwheid en originaliteit van zijn eigen gedachtegoed beter te doen uitkomen. In de hitte van het debat wordt het historisch inlevingsvermogen geweld aangedaan: men lijkt zich steeds moeilijker te kunnen verplaatsen in datgene wat de tegenstander of voorganger nu werkelijk beoogd of betoogd heeft.

Vanzelfsprekend is het niet onbelangrijk bij lezing van dit boek goed voor ogen te houden wat Vries onder wetenschap verstaat. Het is opvallend dat hij het begrip wetenschap niet strak maar ruim definieert (20). Het kan waarschijnlijk moeilijk anders. Wetenschap valt te herken- 
nen aan: een kritische benadering, een rationele beoordeling en discussie en tenslotte een empirisch succesvolle en betrouwbare kennis. Dit zijn alles welbeschouwd weinig concrete omschrijvingen, waar niet iedereen eenzelfde uitleg aan zal geven, ook al bestaat er een consensus over wat 'logisch redeneren' inhoudt. Ik denk dat de auteur een tekst als wetenschappelijk wil kwalificeren als daarin op rudimentaire wijze de zogeheten 'empirische cyclus' zichtbaar is (79). Nu dient men wel te bedenken dat deze 'cyclus' (net als de zogeheten 'hermeneutische cirkel') een ideaaltypische constructie is, een nuttige maar abstracte leidraad om de context of justification door te lichten, maar geen weergave van het concrete proces van wetenschapsbeoefening. Alleen kennis of beheersing van de regels van deze cyclus maakt nog geen wetenschapper. De auteur zal dit alles niet ontkennen denk ik. Maar toch horen we pas an het einde van dit dikke boek heel expliciet dat zijn 'ruime' definitie van wetenschap toch ook een heel beperkte is. Slechts de helft van de wetenschap komt om zo te zeggen aan bod. Zaken als durf, originaliteit en inventiviteit - 'zaken, die de wetenschap vooruit helpen' blijven buiten beschouwing (393-394). Dat is jammer want er ontstaat zo onwillekeurig een weinig historisch en vrij statisch beeld van geschiedbeoefening. Alle aandacht richt zich op de context of justification zonder nauwelijks enige relatie te leggen tot die context of discovery of aandacht te besteden aan hun onderlinge verhouding of wisselwerking. Voor wie de geschiedfilosoof uitsluitend scheidsrechter is, voor wie de geschiedfilosofie laat samenvallen met wetenschapsfilosofie, bestaat in feite geen andere keuze.

In deze 'evaluerende inventarisatie' (zoals de auteur zelf zijn boek betitelt, 21) worden telkens - in bijna ieder hoofdstuk — drie thema's aan de orde gesteld: de rol van generalisaties, de verhouding tussen het structurele en het handelingsperspectief en de methodische onderbouwing. Over het tweede punt (het gehanteerde perspectief) wil ik tenslotte iets zeggen. Het is een belangrijk, zo niet het belangrijkste thema van dit boek, dat immers juist een opvallende perspectiefverandering onder de aandacht brengt. De auteur wil scherp en strak definiëren waar het gaat om begrippen als generalisatie of structuur. Ten aanzien van het begrip perspectief gaat hij wat losser te werk, lijkt hij bewust of onbewust af te zien van een nadere definiëring, hoewel het voor de moderne geschiedwetenschap mijns inziens een fundamentele categorie is. In het begin stelt de auteur, dat de term structuur (structurele geschiedenis) niet alleen duidt op een object, een segment van de werkelijkheid (economische onderbouw, organisatie of denkkader), maar ook verwijst naar een perspectief. In het 'structurele' perspectief gaat de aandacht met name uit naar 'patronen en ontwikkelingen', die wij vanuit onze 'achteraf-kennis' (het 'anachronistische' perspectief van Bertels, 304-305) kunnen ontdekken; in het niet-structurele perspectief staat de beleving (de leefwereld) van de historische actores centraal. De auteur spreekt dan over het 'deelnemers- of actor-perspectief', even later ook over het 'handelingsperspectief' (89-90) en nog weer later in het kader van de figuratie-sociologie wordt gesproken over het wij- en zij-perspectief (303-305). Een perspectief helpt ons de werkelijkheid (ook die van het verleden) te 'structureren'. Het begrip perspectief valt soms ook nauw samen met het begrip theorie in zijn oorspronkelijke betekenis van beschouwingswijze, stelt de auteur in zijn hoofdstuk over de vergelijkende historische sociologie. Zonder een bepaald perspectief kun je bepaalde 'dingen' als 'revolutie' of 'staatsvorming' eenvoudigweg niet zien heet het daar (271).

Zoals gezegd telkens in dit boek duikt de kwestie op naar de verhouding tussen beide perspectieven, resulterend in de volgende merkwaardige vragen: 'Staan zij los van elkaar? Is één van de twee 'beter'? Kunnen de resultaten die zij opleveren, geïntegreerd worden in een beeld of verklaring?' (90). De auteur wekt de suggestie alsof dit vraagstuk pas betrekkelijk recent en wel vanuit de sociologie aan de orde is gesteld. Hij spreekt over een controverse tussen twee sociologieën als 'het grootste wespennest binnen de filosofie van de sociale wetenschap'. Dan 
laat hij er de volgende zin op volgen: 'Naar de geschiedbeoefening vertaald komt het erop neer dat we ons afvragen, hoe hetgeen we achterhalen, wanneer we de ervaringswereld van actores en hun handelen reconstrueren, zich verhoudt tot hetgeen we in het vizier krijgen wanneer we een structureel perspectief hanteren' (90). Hier gebeurt iets merkwaardigs. Waar de moderne geschiedwetenschap sinds 1800 mee geworsteld heeft (of ze nu romantisch of positivistisch gekleurd was, doet er niet toe) wordt ons hier voorgeschoteld als een nieuwe sociologische problematiek. Het gaat hooguit om een nieuwe aangepaste vertaling van een oude problematiek: hoe binnen ons diachrone ontwikkelingsperspectief een plaats in te ruimen voor de belevingswereld (intenties, gevoelens etc.) van de tijdgenoot. Van een puur Nacherleben kon geen sprake meer zijn. Er is een auteur (die in dit boek niet voorkomt en er ook niet in thuis hoort) die op de vraag naar een mogelijke integratie van beide perspectieven een antwoord heeft trachten te geven en alle historische arbeid ziet resulteren in een 'versmelting van horizonten' (H. G. Gadamer). Ik ben het daar niet mee eens, omdat ik meen dat een groot deel van de historische arbeid er juist uit dient te bestaan die 'horizonten' uit elkaar te houden door duidelijk te laten uitkomen wat ons van het verleden scheidt. Slechts bij benadering kunnen we die vroegere leefwerelden reconstrueren door met behulp van datzelfde structurele ('anachronistische') perspectieferachter te komen waarin heden en verleden met elkaar overeenkomen en verschillen.

In dit boek staat zoals gezegd de context of justification centraal. Dat is logisch en alleszins begrijpelijk waar het het eerste en derde thema betreft over respectievelijk de rol van generalisaties en de methodische onderbouwing. Voor een antwoord op de vraag naar de verhouding tussen beide perspectieven (het tweede thema) kan men beter te rade gaan bij de context of discovery. Dat lijkt de auteur ook te beseffen. In het korte tweede hoofdstuk doet hij een poging de fundamentele perspectiefverandering van de laatste decennia te verklaren niet volgens het wetenschapsmodel waarvan hij in dit boek een pleitbezorger is maar gewoon met behulp van een ouderwetse 'impressionistische' beschrijving van het veranderde leef- en denkklimaat (68). Hij wijst op het wegebben van het vooruitgangsgeloof en het verminderde vertrouwen in de wetenschap. Het zijn veelal externe factoren die bepalend zijn (geweest) voor het feit naar welk perspectief op een bepaald ogenblik de voorkeur uitgaat. De eigentijdse vraag en behoefte lijken hier een heel grote rol te spelen. Aan het slot van zijn boek constateert de auteur tot zijn verdriet dat 'leefwereld-historici' en 'structuur-historici' zich teveel in hun eigen wereldje opsluiten. Men profiteert niet of veel te weinig van eikaars bevindingen (406). Dat is jammer en schadelijk voor het vak. De verschillende perspectieven, die men er op na houdt, zijn immers beide constitutief voor de moderne geschiedwetenschap sinds 1800 . Toch is het maar weinigen gelukt een zeker evenwicht tussen beide tot stand te brengen. Zij hebben elkaar nodig, maar toch bijten ze elkaar herhaaldelijk in de praktijk. Waar het ene perspectief overheerst, komt het andere duidelijk in de verdrukking. De opgeworpen vraag of het ene perspectief beter is dan het andere lijkt me een onzinnige vraag en de eis tot integratie heeft iets utopisch. De moderne geschiedwetenschap kent nu eenmaal twee duidelijk te onderscheiden heterogene opgaven, die wel met elkaar samenhangen, maar die nooit tot een homogene doelstelling te integreren zijn. Wie op synchrone wijze leefwerelden tracht te reconstrueren doet nu eenmaal fundamenteel iets anders dan iemand die processen en ontwikkelingen in kaart wil brengen.

P. B. M. Blaas

N. C. F. van Sas, ed., Waar de blanke top der duinen en andere vaderlandse herinneringen (Amsterdam: Uitgeverij Contact, 1995, 158 blz., ISBN 902541372 2). 